FigueroA, Esther 1994: Sociolinguistic metatheory. Oxford: Pergamon.

Foucault, Michel 1980: Power/Knowledge. Selected interviews and other writings 1972-1977. Toimittanut Colin Gordon. Kääntäneet Colin Gordon, Leo Marshall, John Mepham \& Kate Soper. New York: Pantheon books.

Garrett, Peter 2001: Language attitudes and sociolinguistics. - Journal of Sociolinguistics 5 s. 626-631.

Gumperz, John 1982: Discourse strategies. Cambridge: Cambridge University Press.

Halonen, Mia - VaAttovaara, JohanNA 2017: Tracing the indexicalization of the notion "Helsinki s". - Linguistics 55 S. 1169-1195.

Hymes, Dell 1972: Editorial introduction to Language in society. - Language in Society 1 s. 1-14.

- 1974: Foundations of sociolinguistics. An ethnographic approach. Philadelphia: University of Pennsylvania Press.

Lehtonen, Heini 2015: Tyylitellen. Nuorten kielelliset resurssit ja kielen sosiaalinen indeksisyys monietnisessä Helsingissä. Suomen kielen, suomalais-ugrilaisten ja pohjoismaisten kielten ja kirjallisuuksien laitos. Helsingin yliopisto. http://urn.fi/

URN:ISBN:978-951-51-1333-7.

Nuolijärvi, Pirkкo 2000: Sosiolingvistiikka kielentutkimuksen kentässä. Kari Sajavaara \& Arja Piirainen-Marsh (toim.), Kieli, diskurssi \& yhteisö s. 13-38. Soveltavan kielentutkimuksen teoriaa ja käytäntöä 2. Jyväskylä: Jyväskylän yliopisto, Soveltavan kielentutkimuksen keskus.

Preston, Dennis R. 2011: The power of language regard. Discrimination, classification, comprehension, and production.

- Dialectologia s. 9-33.

Silverstein, Michael 2003: Indexical order and the dialectics of sociolinguistic life. - Language and Communication 23 S. $193-229$.

Sorjonen, Marja-Leena - Rouhikoski, Anu - Lehtonen, Heini (toim.) 2015: Helsingissä puhuttavat suomet. Kielen indeksisyys ja sosiaaliset identiteetit. Suomalaisen Kirjallisuuden Seuran Toimituksia 1310. Helsinki: Suomalaisen Kirjallisuuden Seura.

Vertovec, Steven 2007: Super-diversity and its implications. - Ethnic and Racial Studies 30 s. 1024-1054.

\title{
Vuorovaikutuksen näkökulmia imperatiivisten vuorojen rakenteeseen ja käyttöön
}

\begin{abstract}
Marja-Leena Sorjonen, Liisa Raevaara \& Elizabeth Couper-Kuhlen (toim.): Imperative turns at talk. The design of directives in action. Studies in Language and Social Interaction 30. Amsterdam: John Benjamins 2017. 435 s. ISBN 978-90-272-2640-2.
\end{abstract}

Imperative turns at talk: The design of directives in action on mittava imperatiivisia vuoroja vuorovaikutuksessa analysoiva kokoomateos. Marja-Leena Sorjosen, Liisa Raevaaran ja Elizabeth Couper-Kuhlenin toimittama teos koostuu johdannon ja epilogin lisäksi kahdestatoista luvusta. Analyysi kohdistuu hyvin monentyyppisiin kasvokkaista ja puhelinvälitteistä vuorovaikutusta edustaviin aineistoihin, joita analysoidaan multimodaalisesta näkökul- 
masta. Myös kielivalikoima on laaja: mukana ovat englanti, italia, puola, ranska, ruotsi, saksa, suomi, tanska, venäjä ja viro.

Teoksen otsikko pitää sisällään termit imperativi ja direktiivi. Imperatiivi on verbin modus, jonka keskeisenä tehtävänä on pidetty käskyn ilmaisemista (ks. VISK s.v. imperatiivi; vrt. Lauranto 2015). Direktiivit puolestaan määritellään usein lausumiksi, joilla pyritään ohjaamaan toisten osallistujien toimintaa vuorovaikutuksessa (ks. esim. VISK $\$ 1645$; Goodwin 1990; Stevanovic \& Svennevig 2015). Direktiiviset lausumat toteutuvat monesti imperatiiveina, mutta ne voivat toteutua myös muunlaisin kielellisin rakentein (ks. Lauranto 2015).

Direktiivisten lausumien analyysissa on monta tapaa lähteä liikkeelle, ja teoksen eri luvuissa lähtökohdat vaihtelevat. Tämä heijastuu siihen, millaista terminologiaa kirjoittajat käyttävät. Joissakin luvuissa aloitetaan imperatiiviverbeistä tai imperatiivilausumista, jotka koostuvat imperatiiviverbistä ja siihen liittyvästä modaalipartikkelista (Heinemann \& Steensig; Etelämäki \& Couper-Kuhlen; Sorjonen). Toisissa taas lähtökohtana on sosiaalinen toiminta, usein pyytäminen (requesting), joka toteutetaan imperatiivilausumilla (Rossi; Bolden). Osa kirjoittajista nimeää tutkimuksensa kohteeksi direktiivit (Mondada; Raevaara) tai direktiivisen toiminnan (Rauniomaa), ja osa sanoo tutkivansa sitä, miten osallistujat koordinoivat toimintaansa vuorovaikutuksessa, ja fokusoivansa nimenomaan imperatiivisiin vuoroihin (Zinken \& Deppermann). Kaikkia terminologisia valintoja voi pitää analyysin näkökulmasta perusteltuina, ja osaltaan ne heijastelevat myös aikaisemmassa tutkimuksessa tehtyjä valintoja. Terminologista moninaisuutta myös taustoitetaan teoksen johdannossa napakasti.

Imperatiiveja on aikaisemmassa tutkimuksessa analysoitu esimerkiksi typologian ja kielen rakenteen näkökulmasta sekä kulttuurienvälisen pragmatiikan kysymyksistä käsin (ks. esim. Blum-Kulka,
House \& Kasper toim. 1989; Aikhenvald 2010). Tutkimus ei muutamia poikkeuksia lukuun ottamatta ole kuitenkaan perustunut autenttisten vuorovaikutustilanteiden tarkasteluun (ks. kuitenkin Vine 2004; Lauranto 2015). Nyt käsillä oleva teos tuo imperatiivisten vuorojen ja direktiivien tutkimukseen uutta tietoa erityisesti siksi, että siinä analysoidaan imperatiiveja niiden luonnollisissa käyttöympäristöissä eli osana puheenvuoroja ja sosiaalisia toimintoja. Analyyseissa eritellään esimerkiksi sitä, miten imperatiiviverbin sisältävät vuorot rakentuvat, miten ne sijoittuvat osaksi sekvenssejä ja käynnissä olevaa toimintaa ja millaisia sosiaalisia toimintoja niillä toteutetaan.

Teos pohjaa aikaisempaan keskustelunanalyyttiseen direktiivejä ja pyyntöjä tarkastelleeseen tutkimukseen (esim. Wootton 1997; Craven \& Potter 2010; Stevanovic \& Svennevig 2015; Rossi 2012, 2014, 2015) ja tuo siihen tärkeän lisän paitsi yksityiskohtaisen kielellisen analyysin kautta myös lisäämällä ymmärrystä siitä, miten imperatiivivuorot suhteutuvat osallistujien meneillään olevaan konkreettiseen toimintaan. Erilaisissa fyysisissä ja materiaalissa ympäristöissä tapahtuvien vuorovaikutustilanteiden analyysi havainnollistaa hyvin yksityiskohtaisesti, miten imperatiivivuorot rakennetaan ottamaan huomioon se, mitä niiden vastaanottaja on parhaillaan tekemässä ja miten hänen toimintansa todennäköisesti on jatkumassa esimerkiksi ruoanlaittotilanteissa, ajo-opetuksen aikana tai viulutunneilla.

Arvioitavan teoksen luvut on ryhmitelty kolmeen eri osaan. Ensimmäisen osan luvut keskittyvät imperatiivisten vuorojen muotoiluun ja käyttöön kasvokkaisissa konteksteissa. Toisessa osassa käsitellään imperatiivisia vuoroja osana sekvenssejä ja erityisesti tarkastellaan responsseina toimivia imperatiivisia vuoroja. Kolmannessa osassa keskitytään erilaisten epäsymmetristen vuorovaikutustilanteiden analyysiin. 
Imperatiivisten vuorojen rakenne ja käyttö

Teoksen ensimmäinen osa ("Structure and use of imperative turns") koostuu viidestä luvusta, joissa havainnollistuu erinomaisesti, miten imperatiiviset vuorot suhteutetaan siihen, mitä vastaanottaja on juuri tekemässä ja miten sitoutunut hän on siihen toimintalinjaan, jota imperatiivivuoro pyrkii edistämään.

Jörg Zinkenin ja Arnulf Deppermannin luvun ("A cline of visible commitment in the situated design of imperative turns: Evidence from German and Polish") aineisto on peräisin saksan- ja puolankielisistä arkisista ja institutionaalisista tilanteista. He asettavat luvussaan eri tavoin muotoillut imperatiiviset vuorot jatkumolle kielellisesti kaikkien yksinkertaisimmista vuoroista kaikkein kompleksisimpiin. Heidän analyysinsa osoittaa, että imperatiivit muotoillaan kielellisesti yksinkertaisiksi tilanteissa, joissa vastaanottaja on jo suorittamassa toimintaa, johon imperatiivi liittyy, ja joissa imperatiivin sanoittama toiminta hyödyttää sekä imperatiivin esittäjää että vastaanottajaa. Tällaiset kielellisesti yksinkertaiset imperatiivivuorot koostuvat usein pelkästä nopeasti artikuloidusta imperatiiviverbistä. Kielellisesti kaikkein kompleksisimpia ovat imperatiivit, jotka osoitetaan vastaanottajalle, joka on parhaillaan tekemässä jotakin muuta mutta jolla on kuitenkin sosiaalisia sitoumuksia myös imperatiivilla viitattuun toimintaan. Nämä kompleksiset imperatiivivuorot sisältävät imperatiiviverbin lisäksi esimerkiksi vastaanottajan puhuttelua, vuorossa viitattujen objektien kielentämistä sekä vuoron direktiivisyyttä pehmentäviä kielellisiä keinoja. Zinkenin ja Deppermannin luku toimii hyvin teoksen aloittajana havainnollistaessaan, miten imperatiivisissa vuoroissa näkyy vastaanottajaan suuntautuminen ja erityisesti se, miten imperatiivinen vuoro muotoillaan suhteessa vastaanottajan meneillään olevaan ja havaittavan keholliseen toimintaan. Tämä teema on olennainen myös useissa muissa teoksen luvuissa, erityisesti teoksen ensimmäisessä osassa.

Ensimmäisen osan toisessa luvussa ("Precision timing and time embeddedness of imperatives in embodied courses of action: Examples from French") Lorenza Mondada tarkastelee imperatiivisia vuoroja tilanteissa, joita luonnehtii välittömän toiminnan tarve, kiire ja mahdollinen riski. Näissä tilanteissa toiminnan täsmällinen ajoitus on olennaista. Mondada näyttää analyysissaan, miten toiminnan kiireellisyys heijastuu imperatiivisen vuoron muotoiluun. Vuoro on yleensä hyvin lyhyt ja syntaktisesti yksinkertainen: imperatiivimuotoinen verbi esiintyy siinä yksin. Vuoro myös tuotetaan nopeasti. Jos siihen liittyy eleitä, eleet alkavat usein ennen imperatiivimuotoista verbiä, ja näin ollen ne aloittavat direktiivisen toiminnan jo ennen kuin imperatiiviverbiä on artikuloitu. Jälkijäsen eli responssi imperatiiviseen vuoroon tuotetaan Mondadan analysoimissa konteksteissa kehollisesti. Responssi on yleensä samanlinjainen, eli se toteuttaa toiminnan, johon imperatiivivuoro on kehottanut. Responssit tuotetaan niin pian kuin mahdollista, ja näin myös responsseilla suuntaudutaan toiminnan kiireellisyyteen.

Giovanni Rossi analysoi luvussaan ("Secondary and deviant uses of the imperative for requesting in Italian") imperatiivimuotoisia pyyntöjä. Luku pohjaa tekijän aikaisempaan tutkimukseen pyynnöistä (requests) italiankielisissä arkikeskusteluissa (Rossi 2012, 2014, 2015) ja siinä tehtyyn havaintoon imperatiivimuotoisten pyyntöjen painottumisesta tilanteisiin, joissa pyyntö liittyy meneillään olevaan laajempaan toimintalinjaan ja hyödyttää sekä pyytäjää että pyynnön toteuttajaa (vrt. Zinkenin \& Deppermannin artikkeli arvioidussa teoksessa). Tällaisten tapausten ensisijaisuudesta kertoo se, että 
ne ovat frekventtejä ja kielelliseltä muotoilultaan yksinkertaisia. Tässä teoksessa Rossi keskittyy kuitenkin toisenlaisiin tapauksiin, joita hän nimittää toissijaisiksi ja poikkeustapauksiksi.

Toissijaiset imperatiivit liittyvät tilanteisiin, joissa imperatiivimuotoinen pyyntö hyödyttää lähinnä vain pyytäjää. Tällaiset pyynnöt ovat Rossin aineistossa harvinaisempia ja muotoilultaan kompleksisempia kuin ensisijaisen käytön tapaukset. Pyyntöä saatetaan näissä tapauksissa pehmentää partikkeleilla tai muilla keinoilla, ja niihin liittyy toisinaan myös selontekoja, joilla osoitetaan, miten pyyntö liittyy vastaanottajan toimintaan. Poikkeustapauksina käsitellään imperatiivimuotoisten pyyntöjen käyttöä tilanteissa, joissa esimerkiksi interrogatiivin käyttö olisi odotuksenmukaisempaa. Rossin analyysin mukaan tällaisen pyynnön esittäjän toimintaa usein myös kritisoidaan tai sanktioidaan muulla tavoin.

Trine Heinemann ja Jakob Steensig analysoivat kirjoituksessaan ("Three imperative action formats in Danish talkin-interaction: The case of imperative + modal particles bare and lige") kolmea toimintaformaattia (social action format; ks. Fox 2007; Kärkkäinen \& Keisanen 2012) eli imperatiiviverbin ja modaalipartikkelin kokonaisuutta tanskankielisissä keskusteluissa. He osoittavat, että formaatteja käytetään erilaisissa konteksteissa ja erilaisiin vuorovaikutuksellisiin tehtäviin. Imperatiiviverbistä ja modaalisesta partikkelista lige koostuvaa kokonaisuutta käytetään esitettäessä pyyntöä, joka on sikäli vähäinen, että se ei aiheuta pyynnön vastaanottajan toimiin isoa muutosta. Imperatiiviverbistä ja modaalisesta partikkelista bare koostuvalla kokonaisuudella sen sijaan myönnetään lupa toimintaan. Tällä formaatilla myös tuodaan julki luvan pyytäjän ja luvan myöntäjän vuorovaikutusroolit. Lisäksi kirjoittajat analysoivat formaattia, jossa partikkeli bare aloittaa vuoron, joka jatkuu imperatiivi- verbillä. Tällaista formaattia käytetään konteksteissa, joissa edellä on esitetty jonkinlainen ongelma tai vastoinkäyminen; kyseisellä formaatilla esitetään neuvo tuon ongelman ratkaisemiseksi. Tämän luvun analyysi näyttää oivaltavasti, miten sosiaalisen toiminnan formaattien analysointi kokonaisuuksina avaa uusia näkökulmia esimerkiksi juuri imperatiiviverbien ja modaalipartikkeleiden yhdistelmiin ja niiden vuorovaikutuksellisiin tehtäviin.

Ensimmäisen osan viimeisessä luvussa Galina Bolden ("Requests for hereand-now actions in Russian conversation") analysoi venäjänkielisiä arkikeskusteluja. Myös hän lähtee analyysissaan liikkeelle pyytämisestä sosiaalisena toimintona. Boldenin aineisto koostuu suureksi osaksi erilaisista ruokailutilanteista, ja pyyntövuorot liittyvät esimerkiksi eri ruokalajien pyytämiseen. Tavallisimmin pyynnöt toteutetaan imperatiivikonstruktioilla. Boldenin analyysi osoittaa, että venäjänkielisissä arkikeskusteluissa imperatiivimuotoiset pyynnöt ovat tavallisia ja odotuksenmukaisia eikä niitä käsitellä mitenkään ongelmallisina tai esimerkiksi epäkohteliaina. Imperatiivimuotoisiin pyyntöihin liittyy myös vahva oletus siitä, että vastaanottaja toimii pyynnön mukaisesti. Jos pyyntö muotoillaan toisella tavalla (esim. interrogatiivisesti), siihen sisältyy vahvempi olettamus siitä, että vastaanottaja ei ehkä suostu tai pysty toimimaan pyynnön osoittamalla tavalla.

\section{Imperatiiviset vuorot osana direktii- visiä sekvenssejä}

Teoksen toisessa osassa tutkitaan imperatiivisia vuoroja osana direktiivisiä sekvenssejä. Kahdessa luvussa (Sorjonen sekä Keevallik) analysoidaan imperatiivivuoroja, jotka ovat responsseja johonkin edellä esitettyyn. Näissä luvuissa esitetty analyysi on kiinnostavaa luettavaa erityisesti siksi, että imperatiiveja on yleensä tarkasteltu aloittavina toimintoina (etu- 
jäseninä) ja niiden responsiivisesta käytöstä on vähemmän tutkimusta.

Marja Etelämäki ja Elizabeth CouperKuhlen osoittavat luvussaan ("In the face of resistance: A Finnish practice for insisting on imperatively formatted directives"), että suomenkielisissä arkikeskusteluissa direktiivit voidaan tuottaa deklaratiivilausumilla tilanteissa, joissa ensin imperatiiviseksi muotoiltuun direktiiviin ei tule vastaanottajalta toivotunlaista reaktiota. He analysoivat sekvenssejä, joissa imperatiivimuotoista direktiiviä seuraa vuoro, jossa vastaanottaja ei toimi tai jopa kieltäytyy toimimasta imperatiivivuoron edellyttämällä tavalla. Seuraavaksi alkuperäisen imperatiivivuoron tuottaja toistaa direktiivin muotoillen sen yksikön toisen persoonan deklaratiiviksi. Samankaltainen kuvio voidaan löytää myös englanninkielisistä keskusteluista. Kirjoittajat ehdottavat, että deklaratiivit saavat näissä sekvensseissä direktiivisen tulkinnan juuri siitä syystä, että ne sijoittuvat direktiiviseen kontekstiin. Eri tavoin muotoillut direktiivit ovat kuitenkin sävyltään erilaisia: imperatiivivuoroissa korostuu imperatiiviverbin ilmaisema toiminta, kun taas deklaratiivimuotoisissa direktiiveissä korostuu osallistujien välinen suhde ja deonttiset oikeudet.

Marja-Leena Sorjonen analysoi responsseina toimivia imperatiivivuoroja ("Imperatives and responsiveness in Finnish conversation"). Analyysi kohdistuu kahteen vuorotyyppiin: vuoroihin, joissa on vain imperatiiviverbi, ja vuoroihin, joissa on imperatiiviverbi ja vaan-partikkeli. Analyysi osoittaa, että näitä kahta muotoilua voidaan käyttää rakentamaan erilaisia toimintoja riippuen siitä, millaisessa sekventiaalisessa kontekstissa ne esitetään ja mikä on niiden suhde osallistujien laajempaan meneillään olevaan vuorovaikutukselliseen projektiin. Eri tavoin muotoiluilla vuoroilla voidaan toteuttaa erilaisia toimintoja: esimerkiksi antaa lupa, tukea tai kannustaa. Näiden lisäksi imperatii- viksi muotoiltuihin vuoroihin liittyy kuitenkin aina myös vastaanottajan toimintaa tiettyyn suuntaan ohjaileva sävy.

Leelo Keevallikin luku ("Negotiating deontic rights in second position: Young adult daughters' imperatively formatted responses to mothers' offers in Estonian") keskittyy aikuisten tyttärien ja näiden äitien välisiin vironkielisiin puhelinkeskusteluihin. Keevallik analysoi imperatiivimuotoisia responsseja, joilla tyttäret reagoivat äitien edellisessä vuorossa esittämiin tarjouksiin. Äidit tarjoavat tyttärilleen erilaisia palveluksia tai esimerkiksi ruokaa, ja tarjoukset on aina muotoiltu niin, että niiden esitetään hyödyttävän tytärtä. Tarjouksiin liittyy kuitenkin toive tulla esimerkiksi hakemaan tarjotut asiat äidin luota, ja näin ollen kysymys siitä, ketä tarjous lopulta hyödyttää, muuttuu monimutkaisemmaksi. Tyttärien responssit äitien tarjouksiin on kieliopillisesti sovitettu edeltävään vuoroon eli etujäseneen siten, että niissä toistetaan siinä esiintynyt verbi imperatiivimuodossa. Analyysin mukaan nämä responssit osoittavat eriasteista tarjousten vastustusta. Keevallik pohtii, mitä havainnot kertovat äitien ja aikuisten tyttärien vuorovaikutussuhteesta: vastustamalla äitien konkreettisia tarjouksia tyttäret osoittavat esimerkiksi omaa aikuisuuttaan ja riippumattomuuttaan.

\section{Imperatiivit opetustilanteissa ja lää- kärin vastaanotolla}

Teoksen kolmas osa käsittelee imperatiivisia vuoroja epäsymmetrisissä vuorovaikutustilanteissa. Sen ensimmäisessä luvussa Jan Lindström, Camilla Lindholm, Catrin Norrby, Camilla Wide ja Jenny Nilsson analysoivat imperatiivimuotoisia direktiivejä ruotsinkielisillä lääkärin vastaanotoilla ("Imperatives in Swedish medical consultation"). He tekevät havaintoja erityisesti siitä, millainen työnjako on moduloimattomilla imperatiivivuoroilla ja sellaisilla imperatiivivuoroilla, joissa on 
mukana esimerkiksi partikkeleita imperatiivia pehmentämässä. Analyysi osoittaa, että moduloimattomia imperatiivimuotoisia direktiivejä esiintyy erityisesti fyysisen tutkimuksen aikana (ks. myös Sorjonen 2001). Ne eivät yleensä aloita toimintaa, vaan niitä käytetään, kun toiminta on jo käynnissä ja toimintalinja selvä osallistujille. Lääkäri ohjaa tätä toimintaa suorilla imperatiivivuoroilla. Moduloituja imperatiiveja esiintyy erityisesti vastaanottojen aloitus- ja lopetusvaiheissa sekä erilaisten toiminnallisten siirtymien yhteydessä.

Mirka Rauniomaa analysoi luvussaan ("Assigning roles and responsibilities: Finnish imperatively formatted directive actions in a mobile instructional setting") ajo-opetustilanteita, joissa kuljettajat saavat opetusta, koska heillä on vain vähän ajokokemusta. Analyysi havainnollistaa, että kuljettajan toimintaa ohjataan usein direktiivisesti käytetyillä passiivimuodoilla (käynnistetään, kiihdytetään) ja nollapersoonarakenteilla. Nämä muodot osoittavat opettajan suuntautuvan ajo-opetustilanteeseen yhteisenä ja jaettuna projektina. Imperatiiveja sen sijaan käytetään esimerkiksi tilanteissa, joissa kuljettaja on myöhässä tai epäonnistuu jonkin tärkeän toiminnan suorittamisessa taikka joissa hänen täytyy tehdä jokin ajo-opetukseen liittymätön tehtävä. Näissä tilanteissa imperatiivimuotoinen direktiivi osoittaa, että kuljettaja on positiossa, jossa hän pystyy toteuttamaan toiminnan parhaiten itsenäisesti. Imperatiivimuotoja käytettäessä osallistujien toimijuus ja erilaiset osallistujaroolit nousevat siis selvemmin esille. Kaiken kaikkiaan Rauniomaan analyysi havainnollistaa erinomaisesti, miten erilaiset direktiiviset vuorot linkittyvät meneillään oleviin kehollisiin aktiviteetteihin ja osallistumisen mahdollisuuksiin.

Viulunsoitonopetukseen liittyviä hortatiiveja (laitetaan, soitetaan) ja imperatiiveja käsittelee Melisa Stevanovic ("Managing compliance in violin instruction: The case of the Finnish clitic particles - $p A$ and $-p A s$ in imperatives and hortatives"). Hän analysoi, milloin imperatiivi- ja hortatiivivuoroihin yhdistetään - $p A$ - tai - $p A s$-liitepartikkeli. Osallistujina aineistossa ovat viisivuotias oppilas ja hänen opettajansa. Analyysi osoittaa, että imperatiivi- ja hortatiivivuorot, joissa ei ole liitepartikkelia, ovat tavallisia tilanteissa, joissa osallistujat ovat aktiivisesti tekemässä jotakin yhdessä. Liitepartikkeli - $p A$ liittyy aineistoissa erityisesti imperatiivivuoroihin (harvemmin hortatiiveihin) ja esiintyy tilanteissa, joissa opiskelija on juuri edellä tehnyt jotakin väärin tai toiminut ei-toivotulla tavalla. -pAs-liitepartikkeli puolestaan yhdistetään imperatiivi- ja hortatiivivuoroihin tilanteissa, joissa on meneillään siirtymä toiminnasta toiseen. Tällaiset vuorot voidaan kuulla lähinnä kuvauksiksi siitä, mitä seuraavaksi tapahtuu.

Raevaara analysoi luvussaan ("Adjusting the design of directives to the activity environment: Imperatives in Finnish cooking club interaction") suomenkielisiä kokkikerhon vuorovaikutustilanteita. Näissä tilanteissa lapset leipovat tai laittavat ruokaa ja opettaja ohjaa heidän toimintaansa ja antaa neuvoja. Raevaara osoittaa, että opettaja käyttää imperatiivivuoroja toiminnan ohjaamiseen erityisesti tilanteissa, joissa imperatiivin osoittamalle toiminnalle on välitön tarve eli joissa lapsen on odotuksenmukaista heti muuttaa käynnissä olevaa toimintaansa ja joissa on selvää, että hän myös toimii ohjeen mukaan. Deklaratiivimuotoisia ohjeistuksia opettaja käyttää tilanteissa, joissa esimerkiksi aloitetaan uutta toimintaa. Analyysi havainnollistaa, miten erityyppiset direktiiviset muotoilut sovitetaan osallistumiskehikkoon ja miten niitä toisaalta käytetään jäsentämään meneillään olevaa toimintaa osallistujien kesken.

\section{Yhteenveto: yhtäläisyyksiä ja eroja}

Teoksen erityinen vahvuus on tarkasteltavien kielten ja vuorovaikutusaineistojen 
monipuolisuus. Aineistot edustavat hyvin erilaisia vuorovaikutustilanteita. Niitä yhdistää kuitenkin se, että osallistujat ovat tekemässä jotakin konkreettista yhdessä. Analyysit osoittavat, että imperatiivivuorot liittyvät usein osallistujien yhteiseen ja yhteisesti hyödylliseen toimintaan ja että niillä koordinoidaan meneillään olevaa tässä ja nyt -toimintaa. Puhtaasti käskemisfunktiossa tuotetut imperatiivivuorot näyttävät teoksen analyysien valossa harvinaisilta. Erot imperatiivien muotoilussa liittyvät ennen kaikkea siihen, miten sitoutunut vastaanottaja on imperatiivin osoittamaan toimintaan (kehollisesti tai muiden abstraktimpien sitoumusten kautta). Yksityiskohtaisten analyysien avulla teos purkaa arkikäsitystä siitä, että imperatiivimuodot olisivat epäkohteliaita. Analyysit osoittavat, että imperatiivivuoroilla ohjaillaan meneillään olevaa toimintaa, jonka toteutuminen ei ole vain imperatiivivuoron puhujan intresseissä vaan yleensä hyödyttää myös vastaanottajaa.

Teos tarjoaa paljon uusia näkökulmia ja käsitteellisiä työkaluja imperatiivien ja laajemminkin direktiivisen toiminnan analyysiin vuorovaikutusaineistoissa. Toisinaan käsitteellinen moninaisuus tuntuu lukiessa kuitenkin raskaalta, sillä eri kirjoittajat viittaavat osin samoihin ilmiöihin eri käsitteillä. Esimerkiksi Rossi nimeää bilateraalisiksi pyynnöiksi pyynnöt, jotka hänen aineistossaan hyödyttävät sekä pyynnön esittäjää että toteuttajaa. Bolden puolestaan viittaa osin samanlaisiin pyyntövuoroihin nimittämällä niitä low-cost-pyynnöiksi. Koska teos on mittava niin sivumäärän, lukujen määrän, käsiteltyjen aineistojen, kielten kuin analyysinäkökulmienkin puolesta, jonkinlainen yhteenveto näistä teoksessa käytetyistä käsitteellisistä ratkaisuista olisi auttanut lukijaa hahmottamaan näkökulmien moninaisuutta. Peter Auer summaa epilogissaan teoksen artikkeleista hahmottuvia keskeisiä teemoja mutta ei juurikaan ota kantaa esimerkiksi käsitteelliseen moninaisuuteen.
Kehollisuudesta kiinnostuneena keskusteluntutkijana olin erityisen vaikuttunut aineistokatkelmien huolellisesta esittämisestä läpi teoksen. Lähes kaikissa luvuissa litteraatteihin on yhdistetty kuvia, jotka havainnollistavat analyysin kohteena olevia ilmiöitä erinomaisesti. Tämä lisää analyysien läpinäkyvyyttä ja uskottavuutta ja tekee lukukokemuksesta miellyttävän. Multimodaalinen analyysi osoittaa havainnollisesti, miten imperatiivisten vuorojen muotoilussa otetaan huomioon vastaanottajan toiminta ja miten ne sovitetaan meneillään olevan toiminnan materiaaliseen ja temporaaliseen kontekstiin. Teos tuo myös paljon empiiristä, autenttisiin aineistoihin pohjautuvaa tietoa imperatiivisten vuorojen kielellisestä toteutuksesta typologisesti erilaisissa kielissä, ja siksi se on varmasti kiinnostavaa luettavaa myös kieltenvälisistä eroista ja samankaltaisuuksista kiinnostuneille kielentutkijoille. Imperatiivien analyysissa keskeisiä ovat kysymykset siitä, kenellä on oikeus ohjailla muiden toimintaa ja millaisin perustein tämä oikeus rakentuu. Osallistujien deonttiset oikeudet ja vastuut (ks. Stevanovic \& Peräkylä 2012) ovat tästä syystä keskiössä monessa luvussa. Uskonkin teoksen kiinnostavan erityisesti kaikkia keskusteluntutkijoita mutta myös yleisemmin ihmisten välisestä vuorovaikutuksesta ja sen jäsentyneisyydestä kiinnostuneita tutkijoita.

Kokonaisuudessaan teos on vahva näyttö sen puolesta, miten autenttisiin vuorovaikutusaineistoihin perustuva tutkimus auttaa ymmärtämään syvemmin ilmiötä, joka on ihmisten välisessä vuorovaikutuksessa olennainen mutta josta aikaisempi tutkimus ja erityisesti kieliopit ovat tarjonneet selvästi yksiulotteisemman kuvan.

\section{NiINA LILJA etunimi.sukunimi@tuni.fi}

Kirjoittaja on suomen kielen yliopistonlehtori Tampereen yliopistossa. 


\section{Lähteet}

Aikhenvald, Alexandra 2010: Imperatives and commands. Oxford: Oxford University Press.

Blum-Kulka, Shoshana - House, Juliane - Kasper, Gabriele (toim.) 1989: Cross-cultural pragmatics. Requests and apologies. Norwood, NJ: Ablex Publishing Corporation.

Craven, Alexandra - Potter, JonaTHAN 2010: Directives. Entitlement and contingency in action. -Discourse Studies 12 s. 419-442.

Fox, BARBARA 2007: Principles shaping grammatical practices. An exploration. - Discourse studies 9 s. 299-318.

GoOdWIn, MARJORIE 1990: He-said-shesaid. Talk as social organization among black children. Bloomington, IN: Indiana University Press.

Kärkkäinen, Elise - Keisanen, Tiina 2012: Linguistic and embodied formats for making (concrete) offers. - Discourse Studies 14 S. 587-611.

Lauranto, Yrjö 2015: Direktiivisyyden rajoja. Suomen kielen vaihtokauppasyntaksia. Helsinki: Helsingin yliopisto.

Rossi, Giovanni 2012: Bilateral and unilateral requests. The use of imperatives and $M i X$ ? interrogatives in Italian.

- Discourse Processes 49 s. 426-458.

- 2014: When do people not use language to make requests? - Paul Drew \& Elizabeth Couper-Kuhlen (toim.), Requesting in social interaction s. 303-334. Amsterdam: John Benjamins.

- 2015: The request system in Italian interaction. Nijmegen: Radboud University.

SORJONEN, MARJA-LEENA 2001: Lääkärin ohjeet. - Marja-Leena Sorjonen, Anssi Peräkylä \& Kari Eskola (toim.), Keskustelu lääkärin vastaanotolla s. 89-111. Tampere: Vastapaino.

Stevanovic, Melisa - Peräkylä, Anssi 2012: Deontic authority in interaction. The right to announce, propose and decide. - Research on Language and Social Interaction 45 s. 297-321.

Stevanovic, Melisa - Svennevig, Jan 2015: Introduction. Epistemics and deontics in conversational directives.

- Journal of Pragmatics 78 s. 1-6.

Vine, Bernadette 2004: Getting things done at work. The discourse of power in workplace interaction. Amsterdam: John Benjamins.

VISK = HAKULINEN, AULI - VILKUNA, Maria - Korhonen, Rittta Koivisto, Vesa - Heinonen, Tarja RittTa - AlHo, IrJa 2004: Iso suomen kielioppi. Helsinki: Suomalaisen Kirjallisuuden Seura. http://scripta.kotus.fi/visk.

Wootton, Anthony J. 1997: Interaction and the development of mind. Cambridge: Cambridge University Press.

\section{Korpuslingvistiikka kohtaa historiantutkimuksen}

\author{
Anthony McEnery \& Helen Baker: Corpus \\ linguistics and 17th-century prostitution. \\ Computational linguistics and history. \\ Research in Corpus and Discourse. \\ Lontoo: Bloomsbury 2017. $257 \mathrm{~s}$. \\ ISBN 978-1-4725-0609-2.
}

Muistiorganisaatiot, kuten kirjastot, arkistot ja museot, ovat viime aikoina niin Suomessa kuin ulkomailla digitoineet kokoelmiaan ja näin avanneet ne uudella tavalla tutkimuksen aineistoiksi. Koska monet digitoiduista kokoelmista ovat pääsään- 